\title{
Voicing the Suppressed Female Voices in a Male-Chauvinistic Society: A Study of Vijay Tendulkar's Silence! The Court is in Session
}

\author{
Suresh Kumar \\ Assistant Professor \\ Department of English \\ Govt. College Seraj, Lambathach \\ Mandi, Himachal Pradesh, India \\ vijaysuresh8890@gmail.com
}

\begin{abstract}
Vijay Tendulkar (1928-2008) is considered a prominent Indian playwright, movie and television writer, literary essayist and social commentator primarily in Marathi in the twentieth century. The playwright acquaints the readers or the audience with the Indian sociocultural milieu through the journey of characters in Silence! The Court is in Session.This paper aims at analyzing the perceptions of the people towards women in a male-dominated, patriarchal society. The paper will analyze that whether social sanctity, morality, ethics, values are applied to both genders i.e. man and women with the same lenses or favours any of them. If there are dual standards for measuring the character of an individual based on gender, how can one hope for justice? This paper will give an expression to the silenced, the hushed up, the repressed, the suppressed and the oppressed voices,liberating the women while interrogating the male-chauvinistic world.
\end{abstract}

Keywords: Suppressed Female Voices, Social Sanctity, Morality, Male-Chauvinistic 
Silence! The Court is in Session is an English translation of Vijay Tendulkar's Marathi play Shantala! Court Chalu Aahe written in 1963. The play is in the form of a play within a play. Tendulkar projects a Mumbai based theatre group that is committed to spreading social awareness in society by performing issue-based plays, and social work is the thread that binds all the actors together throughout the play. This theatrical troupe reaches a village community hall and prepares for the rehearsal of the play to be performed that evening. The actors have decided to perform a mocktrial protesting against President Johnson's production of atomic weapons. All the troupe members reach the hall following Mrs Benare except Professor Damble and Rawte, and when it is almost confirmed that the absentees would not be able to reach, and perform tonight, they make a few changes in the script in the absence of Mrs LeelaBenare. While playing the role of a public prosecutor Mr Sukhatme calls the witnesses i.e. Ponkshe, Karnik, BaluRokde, Mr Samant, the local villager, Mrs Kashikar into the witness box with one or the other charges on Mrs Benare under the judgments of $\mathrm{Mr}$ Kashikar. At the beginning of the trial, Mrs Benare takes it lightly as she was not the accused in the predefined script, but everyone either pleads or reprimand her to be serious, and she is charged with the crime of infanticide, the crime of desiring her maternal uncle, the crime of bearing an illicit child as an unwed mother, her illegal relationship with Professor Damble, Charges from Ponkshe and Karnik of her attempts into marrying her, and finally charge of the crime of attempting suicide by having poison. Ponkshe and Karnik visit the witness box twice to put up their charges. Whenever she breaksout to explain her part under the spell of emotions, she is silenced and not allowed to speak. Most of the time, her voice is suppressed by the lawyer, by the judge, even by other characters.

To emancipate the status of women in a family and largely in society,female writers started expressing their anxiety regarding the role of a woman in society from the late eighteenth century, although after 1960s it took the form of a movement. Mary 
Wollstonecraft's A Vindication of the Rights of Women (1792)responds to the educational and political theorists of the eighteenth century like Milton, Pope, and Rousseau who believed that women should not obtain a rational education. Here, Wollstonecraft argues that women are also human beings and deserve the same educational as well as other rights like men, and treating them as a mere property or ornament for men is against the moral foundation of the society (Nayar 85). Olive Schreiner's Women and Labour (1911), and Virginia Woolf's A Room of One's Own (1929) vividly portray the unequal treatment given to women seeking education and alternatives to marriage, and motherhood, and a section of Simone de Beauvoir's The Second Sex (1949) projects the depiction of women in D. H. Lawrence's novels. However, some male writers seeking reformation in the status of women express their voices which include Stuart Mill's essay“The Subjugation of Women” (1869) and Friedrich Engels' The Origin of Family(1884) (Barry 116).Pramod K Nayar writes, "Feminist theory argues that the representation of women as weak, docile, innocent, seductive or irrationalsentimental is rooted in and influences actual social conditions, where she does not have power, is treated as a sex-object or a procreating machine, has fewer political and financial rights and is abused" (83). Whereas M.H. Abrams writes that much of the feminist literary criticism that continues in our time has be interrelated with the movement by political feminists for social, legal, cultural freedom and equality (124).

The playwright shows that how a female is not given a chance to give her opinions regarding some twist relating to the rehearsal of the play to be performed in the night through the character of Miss Benare who is the first among the troupe members to reach the village community hall along with Mr Samant, a villager. Although after reaching the hall, all the members discuss the setting of the trial court like:

KASHIKAR. I wander, should we have the judge's chair this side or that? 
KARNIK. Here, of course. The entrance is over there. That room next door can be used for the judge. You can enter from there. President Johnson will stand over here like this-

SAMANT. [amaged] President Johnson!

KASHIKAR. No, no. Johnson's dock should be left over there. So when I speak as a Judge-

KARNIK. I don't agree. If you look at it from audience's point of view, it should be right here-

SUKHATME. Mr Karnik, I shall prosecute you for seeing things from audience's point of view! And you a man of modern theatre! [a lawyer's laugh.](21)

But when the absence of Professor Damble and Rawte is confirmed, all the members plan the change in the play to be performed in the absence of Miss Benare, they decide that she will play the role of an accused. Charges against her are also decided by them to whom she is completely ignorant. Sukhatme proposes her name and the rest consent without a second thought:

SUKHATME. We don't need to take any of you. Kashikar, Let's have a different kind of accused. Eh? Let's have our Miss Benare! Eh, Ponkshe? What d'you think of my choice?

PONKSHE. It's good. (31)

As all had been planned in her absence and when she joins them back, Ponkshe tells Miss Benare that she has been arrested on suspicion of a crime of a grave nature, and has been brought as a prisoner before the bar of this court. In the meanwhile, Kashikar comes and seats himself on the Judge's chair on the dais, and orders all to settle down. The situation turns Miss Benare stunned and thoughtless when Kashikar enquires her: 
KASHIKAR. [Sitting at the table with the dignity of a judge] Prisoner Miss LeelaBenare, under section 302 of the Indian Penal Code, you have been accused of the crime of infanticide. Are you guilty or not guilty of the aforementioned crime? (34)

When Miss Benare turns thoughtless and does not answer for the crime, reprimands are issued for abrogating the authority of the counsel and for obstructing the due process of the law from the Judge, Kashikar whose actions mock the real Court proceedings. Sukhatme, the public prosecutor asserts that 'Woman is a wife for a moment, but a mother forever' (42). He argues that the concept of motherhood is pious as a woman has been acknowledged as the mother of all mankind and appeals for the suitable punishment for the committed crime disregarding her sobbing and viewpoints.

To prove charges against the loose character of Miss Benare, witnesses Ponkshe and Karnik inform the court that she has attempted to marry both of them. Ponkshe informs the court that, "She made known her desire to marry me" (84) as she was pregnant from Professor Damble. He says:

PONKSHE. Then she said, 'She worshipped that man's intellect. But all he understood was her body.' She added other things. On the same lines. How she could not find a place in Damble's life. His- (89)

Besides this, Rokde also reveals Miss Benare's sensuous advances towards him. He attempts to prove her character as immoral one.

Thereafter, Miss Benare's relationship is brought into light by Rokde and Mr Samant which is considered illegal. She gets interrogated for her affair:

ROKDE. Yes, I went there in the evening. As night was falling. And there-she was!Miss Benare.

ALL. Who? 
ROKDE. [looking at Benare] Now laugh! Make fun of me! This lady was there. Damble and this-Miss Benare! (53-54)

On the other hand, Mr Samant visits Professor Damble after half an hour after Rokde's visit is compelled to say as per the new script that he has seen Professor Damble in that evening both had locked themselves inside the room. Earlier Mr Samant says that he lives in a village and he has never been to Professor Damble's room in Bombay as he does not know him. The rest of the actors, remind him that the trial is imaginary and charges are also imaginary only the accused is the real one. After being convinced, Mr Samant opens up about the situation and says that he had heard a strange crying of Miss Benare. Professor Damble's character is not questioned like Miss Benare. In case of such an affair a female is considered the one who carries a bad culture and tradition whereas it does not apply to her male counterparts.

The playwright showcases the perception of the male chauvinistic society while interrogating the individuality of women as Mr Kashikar points out:

KASHIKAR.All right. She's not less than thirty-four. I'll give it to you in writing! What I say is, our society should revive the old custom of child marriage. Marry off the girls before puberty. All this promiscuity will come to a full stop. If anyone has ruined our society, it's Agarkar and Dhondo Keshav Karve. That's my frank opinion, Sukhatme, my frank opinion. (73-74)

Here, whatever opinion or recommendation is passed by the Judge results from the stereotypical patriarchal mindset of the society which does not grant liberty to women, and where she is considered as a toy in the hands of males in the family or society. His suggestion of marrying off a girl against her wishes seems dictatorial. Moreover, he considers the social reformers like Gopal Ganesh Agarkar and Dhondo KeshavKarve as enemies to the patriarchal structure of the society because they raised their voice in favour of women bringing reforms by emancipating them from orthodox traditions. When Mrs Kashikar is asked that how a girl 
can stay bachelor till the age of thirty-two, she adds that it is quite easy for someone when everything is available without being wedded, and one wishes to escape from ones' responsibility. She also attempts to prove her adulterous. She also adds that when a woman starts earning her livelihood, it turns everything wrong in society as she starts taking her individual decisions. Mrs. Kashikar does not like Miss Benare's freely laughing and mixing up with the male actors even.

Thereafter, Miss Benare is identified a criminal for attempting to commit suicide when Ponkshe reveals that he caught her carrying"a bottle of Tik-20" (84) in her purse. Later Karnik also informs the court about her attempt to suicide at the age of fifteen resulted from the "disappointment in love" (93) with her maternal uncle. Sukhatme states her affair with her maternal uncle immoral. No one speaks a word about the intensions of her maternal uncle. Breaking the norms of the court, when the judge, Mr. Kashikar was in the witness box talks about the dismissal of Miss Benare from the school as a teacher, she attempts to drink the poison, but Karnik strikes it away at the moment.

While briefing the counsel for the prosecution, Sukhatme says that the charges against Miss Benare are dreadful as the accused has made a heinous blot on the sanctified brow of motherhood. The character of Miss Benare is immoral. Her character has darkened social and cultural values. Besides the crime of infanticide, she has committed a more heinous crime i. e.unwed motherhood which has always been considered a great sin by religion and tradition. If the offspring from such an illegal union is permitted, it would have more horrifying results as immorality can flourish and the institution of marriage might extinguish. He says:

SUKHATME.The accused has plotted to dynamite the very roots of our culture, our pride in ourselves, our culture and our religion. It is the sacred and imperative duty of your Lordship and every wise and thoughtful citizen amongst us to destroy that plot at once. No allowance must be made because the accused is a woman. A 
woman bears a grave responsibility of building up the high values of society. (102)

Therefore, Sukhatme appeals to take a stern and inexorable view of the convict's crime objectively.

Lastly, the content of the mock trial comes out to be the real-life of Miss Leela Benare. When Miss Benare is given chance to speak, she says that she has to say a lot as "I haven't said a word" (102) for years. She confesses the charges against her while bursting out emotionally. She says that sometimes life leads an individual where suicide feels more joyous than living in this inhumane world. Speaking about Mr Kashikar's appeal of firing out from her job as a school teacher, she says, "For what sin are they robbing me of my job, my only comfort? My private life is my own business. I'll decide what to do with myself; everyone should be able to!" (104). She acknowledges that she fell in love with her mother's brother who also appreciated her but at the age of fourteen she did not know that it was a sin. She also insisted to get married to him, but all including her mother objected and at the same time her lover also ran away, therefore being dejected, she attempted to commit suicide. Thereafter, she admits that she fell in love again referring to Professor Damble as a mature and intellectual love. She says:

As a grown woman, I threw all my heart into it; I thought, this will be different. This love is intelligent. It is love for an unusual intellect. It isn't love at all-it's worship! But it was the same mistake. I offered my body on the altar of my worship. And my intellectual god took the offering and went his way. He didn't want my mind, or my devotion-he didn't care about them! [Feebly]. He wasn't a god. He was a man. For whom everything was of the body, for the body! That's all! Again, the body! [screaming]. This body is a traitor! (105-106) 
Miss Benare's outbursting interrogates the typical mentality of the patriarchal set-up that it is only the woman who carries the culture, traditions, and customs.

After Miss Benare's time is over for explanation, the Judge, Mr Kashikar takes his position to pass on his judgments. While announcing the punishment the judge says that paying attention to the terrible crimes she has committed, there is no space for forgiveness. He states social customs of supreme significance. Marriage is the foundation for the stability of society and motherhood must be kept sacred and pure. The morality which, she has shown through her conduct is the morality she has planned to impart to the youth of the upcoming generation. The court has not an iota of doubt about this. Therefore, not only the present but also the futuristic society would have been endangered by her misconduct. The school administrationalso deserves special patting for removing her from her job. No memento of her sin should remain for future generations. The judge announces, "Therefore this court hereby sentences that you shall live. But the child in your womb shall be destroyed" (108). After listening to the sentence, Miss Benare turns unconscious and others rush towards her to remind her that it was just a mocktrial.

The above depiction either shows the mockery of the proceedings of the Indian court or the projection of sin and crime as per the lenses of the patriarchal system of India, nevertheless the portrayal of a woman in the form of Miss Benare and treatment of her by all the characters and their perceptions are of great symbolical significance. Whatever might have been the reasons for not rehearsing the pre-decided play, but consensus on the new content of the trial reveals the mentality of the society. The content is unanimously decided by the rest of the actors especially the majority of the male characters. Moreover, the collection of charges gets originated from the stereotypical mindsets of the male-chauvinistic society. Although the accused attempts to defend the charges against her, but the preassumptions about her does not allow the male counterparts to listen to her. No one shows 
patience to listen or understand the circumstances leading her to commit suicide. No one questions the character of her maternal uncle whom she falls in love with, and desires to marry. From the perceptions of society, her conduct shows immorality, but not the character of her maternal uncle who equally loves, admires and desires her. Similarly, she is accused of carrying a child in her womb as an unwed mother from a man, Professor Damble, stigmatizing the chastity of motherhood, but again, no one questions the parallel concept i.e. the chastity of fatherhood. No one attempts to understand the level of her depression leading to suicide. When Miss Benare expresses her love before her male counterparts like Ponkshe and Karnik respectively and desires to marry them, none of them takes it seriously as she might be wishing to settle down now permanently after great emotional upheavals.

Moreover, every time Miss Benare is pushed to the peripheries by her companions whether in her real-life or her theatrical troupe. The playwright presents the attitude of the people towards women and towards the functioning of the law courts in late twentiethcentury India. He focuses on the dominating issues of sin and crime like prohibited love, multiple love affairs, infanticide, unwed motherhood, and self-esteem leading towards suicide prevalent in Indian society. However, oppression of the women and suppression of female individuality becomes the focal point of the play, and while portraying the various episodes of women subjugation, the playwright seeks women emancipation desiring a radical change in the male-chauvinistic world. 


\section{Works Cited}

Abrams, M.H., and Geoffrey Galt Harpham.A Glossary of Literary Terms.Cengage Learning India Private Limited, 2018.

Barry, Peter. Beginning Theory. Viva Books Private Limited, 2013.

Nayar, PramodK..Contemporary Literary and Cultural Theory. Dorling Kindersley (India) Pvt. Ltd, 2010.

Tendulkar, Vijay. Silence! The Court is in Session. Trans. Priya Adarkar.Oxford University Press, 2017. 